\title{
CHARACTERIZATION OF LACTIC ACID BACTERIA AND ANTIMICROBIAL ACTIVITY IN SUI WU'U FROM BAJAWA DISTRICT, NUSA TENGGARA TIMUR, INDONESIA
}

\author{
ROSALINA YULIANA AYEN*, ENDANG KUSDIYANTINI, SRI PUJIYANTO
}

Department of Biology, Faculty of Science and Mathematics, Diponegoro University, Jl. Prof. Soedarto, S. H., Tembalang Semarang - 50275, Central Java, Indonesia. Email: ayenrosalinayuliana@gmail.com

Received: 02 January 2020, Revised and Accepted: 30 January 2020

\section{ABSTRACT}

Objective: This research aimed to isolate, determine the characteristics of lactic acid bacteria (LAB) of Sui Wu'u from Bajawa, Nusa Tenggara Timur and identify LAB using $16 \mathrm{~S}$ rRNA potential as antimicrobial activity against pathogenic bacteria.

Methods: Sui Wu'u which has been stored for 6 months was obtained from Bajawa district, inoculated on de Man Rogosa-Sharpe Agar (Merck) + 0.5\% $\mathrm{CaCO3}$, purification of $\mathrm{LAB}$, characterization of selected isolates, biochemical test, tolerance test for $\mathrm{pH}$, viability to test temperature, and content $\mathrm{NaCl}$, determination of antimicrobial action by the agar well disk diffusion method using antibiotic (Amoxicillin) as a control and as indicator bacteria (Staphylococcus aureus and Escherichia coli) and isolation of genomic 16S rRNA; molecular identification.

Results: Based on research results obtained five isolates of LAB, Gram staining the LAB isolated from Sui Wu'u showed that the isolated bacteria (bacilli and coccus) are Gram-positive, catalase-negative and the isolates have tolerance of viability at temperatures of $10^{\circ} \mathrm{C}$, $45^{\circ} \mathrm{C}$, and $50^{\circ} \mathrm{C}$ and to salinitas of $4 \%$ and $6.5 \%$. The inhibitory zone LAB isolates (2PKT) against E. coli bacteria (20 mm) and $S$. aureus (12 mm), and (2PKB) against E. coli bacteria $(17 \mathrm{~mm})$ and $S$. aureus $(10 \mathrm{~mm})$. The two selected isolates were identified as Lactobacillus fermentum strain HB bacteria with $100 \%$ identification value and $98.93 \%$ query cover and L. fermentum strain HT with $100 \%$ identification value and $99.23 \%$ query cover.

Conclusion: L. fermentum from Sui Wu'u has antibacterial activity against Staphylococcus aureus and Escherichia coli.

Keywords: Antimicrobial, Fermented pork, Lactic acid bacteria, Sui Wu'u.

(C) 2020 The Authors. Published by Innovare Academic Sciences Pvt Ltd. This is an open access article under the CC BY license (http://creativecommons. org/licenses/by/4. 0/) DOI: http://dx.doi.org/10.22159/ajpcr.2020.v13i4.36760

\section{INTRODUCTION}

Sui Wu'u is a traditional food from Flores, East Nusa Tenggara, which is spontaneously fermented pork well known in Bajawa. Sui Wu'u is a form of the skill of the ancients to preserve pork. Preservation of pork is done by mixing cornstarch and salt in bamboo (Tuku). Ideally eaten after being stored for 6 months, the length of time it stores can affect the taste and the longer the time it stores the tastes better but does not damage the texture of the meat.

Fermented foods have the potential to be developed as functional foods. Functional food is now important for the human body due to its benefits in the health field with the content of compounds contained in it [1]. Fermented food is a food product that involves microorganisms in the manufacturing process. The fermentation process was originally a technique conducted for the preservation of food products, but the development of technology in the field of fermentation has enabled humans to produce various products that cannot be synthesized in the body and are difficult to produce through chemical processes [2].

Several in vitro studies have been conducted to lactic acid bacteria (LAB), Lactobacillus fermentum [3], Lactobacillus plantarum, Lactobacillus casei, Lactobacillus salivarius, Lactobacillus futsaii [4], Pediococcus pentosaceus, and Pediococcus acidilactici [5] are LAB isolated from various traditional Indonesian fermented foods. Lactobacillus is one of the most important genera of LAB $[5,6]$. These organisms are also known to produce various compounds such as bacteriocin which can antagonize the growth of some pathogenic bacteria in foods $[7,8]$. LAB are regarded as a major group of probiotic bacteria and have been used successfully to treat acute infantile diarrhea and various diarrheal illnesses $[9,10]$.
The LAB are conventionally used to improve immune system also used in pharmaceutical as an alternative of antibiotic [11], antimicrobial [12], anticancer [13], antidiabetic [14], anthelmintic [15], immunomodulatory [16], lactose intolerance, as well as bio preservatives in food [16,17], and improvement of gut microflora or to manage gutrelated problems [18]. One product that can be produced by fermentation is an antibacterial compound. One of Indonesia's fermented foods whose manufacturing processes involve LAB is Sui Wu'u. This study aimed to investigate the antimicrobial activity LAB isolated from fermented food (Sui Wu'u) from Bajawa, Flores, Nusa Tenggara Timur has yet to be studied.

\section{METHODS}

\section{Sample and materials}

Sui Wu'u has been fermented for 6 months and was obtained from Bajawa, Flores, East Nusa Tenggara, Indonesia. The indicator bacteria Staphylococcus aureus and Escherichia coli were kindly supplied from the Department of Biology, Faculty of Science and Mathematics, Universitas Diponegoro.

\section{$\mathrm{LAB}$ isolation and purification}

About $1 \mathrm{~g}$ of each Sui Wu'u sample was mixed with $9 \mathrm{ml}$ of sterile $\mathrm{NaCl}$ $0.85 \%$ [19]. An appropriate dilution $\left(10^{-6}-10^{-7}\right)$ was made and inoculated on de Man Rogosa-Sharpe (MRS) Agar (Merck) + 0.5\% CaCO3 [20] medium by spread plate and incubated at $37^{\circ} \mathrm{C}$ for $48 \mathrm{~h}$ [19]. Colonies with the surrounding clear zone were randomly selected on each plate. A single colony was then transferred by an ose needle to MRS agar to isolate the colony by the streak method and incubated for $24 \mathrm{~h}$ at $37^{\circ} \mathrm{C}$.

\section{Isolate characterization}

Isolates were examined by Gram staining and catalase reaction tests and the cell shape was evaluated microscopically. Gas production from 
glucose was tested using a Durham tube and MRS broth to determine the fermentation type. Then, the isolates will be tested for tolerance to $\mathrm{pH}$, viability to temperature, and $\mathrm{NaCl}$. Phenotype characterization was based on Bergey's Manual of Determinative Bacteriology [21]. Isolates were stored in medium MRS agar at $4^{\circ} \mathrm{C}$ and were for further analyzes [21]

\section{Preparation of bacterial suspension test (E. coli and $S$. aureus)}

The growing stock of bacterial cultures of E. coli and S. aureus was taken with sterile ose wires and then suspended in a test tube containing $9 \mathrm{ml}$ of sterile distilled water to obtain the turbidity of the bacterial suspension equal to the turbidity of the standard solution McFarland 0.5 . Turbidity standard is intended to replace bacterial calculations one at a time and to estimate cell density to be used in antimicrobial testing procedures, which means the concentration of bacterial suspension is $10^{8} \mathrm{CFU} / \mathrm{mL}$. Preparation of standard solution by McFarland preparation $9 \% \mathrm{H}_{2} \mathrm{SO}_{4}$ solution of $9.95 \mathrm{~mL}$ was mixed with $1 \% \mathrm{BaCl}_{2}$ solution of $0.05 \mathrm{~mL}$ in a test tube. Then, shaker untill homogen [22].

\section{Preparation of LAB suspension}

$\mathrm{LAB}$ isolates from the selection taken 1 ose were grown on MRS agar medium, incubated at $37^{\circ} \mathrm{C}$ for $24 \mathrm{~h}$. Then taken with a sterile ose wire and then suspended in a test tube containing $9 \mathrm{~mL}$ of sterile distilled water to obtain the turbidity suspension of bacteria equal to the turbidity of the standard solution McFarland 0.5 [23].

\section{Antimicrobial assay}

The testing of antibacterial activity by LAB from the Sui Wu'u fermented food on the growth of pathogenic bacteria was conducted by the disk diffusion method (Kirby-Bauer) using the smear technique and amoxicillin $100 \mu \mathrm{g} / \mathrm{mL}$ as a positive control [24-26]. Pathogenic bacteria were etched on the surface of MRS media with sterile cotton buds left for $\pm 5 \mathrm{~min}$. Sterile disc paper is soaked in each vial bottle containing a LAB suspension, soaking is done for $\pm 30 \mathrm{~min}$. Disc paper is placed on the media using tweezers according to the pattern of Hudzicki [27]. The size of the inhibition zone indicating antibacterial activity of the isolate was measured after $24 \mathrm{~h}$

\section{Molecular identification}

DNA isolation was conducted using the Chelex method [27]. Identification of LAB by 16S rRNA was done using 27F (5'TACGGYTACCTTGTTACGACTT-3') and 1492R (5'-AGAGTTTGATCCTGGCTCAG-3'). Amplification was conducted using a thermal cycler chain reaction polymerase chain reaction (PCR). The PCR conditions were as follows: Initial denaturation at $95^{\circ} \mathrm{C}$ for $1 \mathrm{~min}$, followed by 35 cycles of denaturation at $94^{\circ} \mathrm{C}$ for $15 \mathrm{~s}$, annealing at $55^{\circ} \mathrm{C}$ for $15 \mathrm{~s}$, and a final extension at $72^{\circ} \mathrm{C}$ for $4 \mathrm{~min}$. The PCR products were analyzed on $1.0 \%(\mathrm{w} / \mathrm{v})$ agarose gel electrophoresis (Mupid-exU submarine electrophoresis system, Advance) in $\times 1$ tris-acetate-EDTA buffer at $100 \mathrm{~V}$ for $30 \mathrm{~min}$. It was visualized on a gel documentation system (Biodoc Analyze, Biometra, USA). Purified PCR products were sequenced with $16 \mathrm{~S}$ rRNA primers. Sequences of the whole gene fragment were used for similarity search against NCBI GenBank database using the Basic Local Alignment Search Tool (BLAST) program available at website https://blast.ncbi.nlm.nih.gov/Blast.cgi. The phylogenetic tree of LAB was constructed with MEGA 10 software (Proprietary Freeware, Pennsylvania State University) and neighborjoining methods were performed to test confidence with bootstrap data set of 1000 times [28].

\section{RESULTS}

Isolation and characterization of LAB

LAB were isolated by MRS agar medium with the addition of $0.5 \%$ $\mathrm{CaCO}_{3}$ by dilution method. Isolates were selected that there is a clear zone around the colonies. Isolates that form a single colony and have a clear zone are inoculated on the MRS agar medium to obtain a pure single colony. Reinoculation was conducted 5 times until pure bacteria culture was discovered. The isolation results obtained were five isolates, namely, $2 \mathrm{PKB}, 2 \mathrm{PKT}, 2 \mathrm{KH}, 2 \mathrm{ST}$, and $3 \mathrm{SP}$. Colony morphology obtained by rounded shape, punctiform, flat, and convex surface and milky white (Table 1).

Five isolates that characteristic morphological cell categorized as Grampositive bacteria. The Gram stain results revealed that the LAB isolated of Sui Wu'u from Bajawa was rods (bacilli and coccus) (Fig. 1).

Morphological characterization consists of Gram staining, observation of cell shape, and formation of endospores. The physiological test performed is the motility test. Biochemical tests are catalase tests. Based on Bergey's manual of determinative bacteriology [21], LAB have characteristics of Gram positive, non-porous, negative catalase, and non-motile. The results of the identification test of LAB can be seen in Table 2.

All isolates obtained were Gram positive, rod shaped, coccus, non-sporeforming, gave a negative reaction to the catalase test, and non-motile. In this study, LAB isolates Sui Wu'u was able to survive at $\mathrm{pH} 4.4$, tolerance to $\mathrm{NaCl}$ concentration and can grow well at various temperatures.

\section{Antimicrobial assay}

Based on the results of research conducted by LAB from Sui Wu'u can be antagonistic to pathogenic bacteria. Two isolates showed a zone of inhibition against pathogenic bacteria, namely, 2PKB and 2PKT (Fig. 2).

Inhibition zone diameter against pathogenic bacteria $E$. coli (2PKB:17 mm) (2PKT: $20 \mathrm{~mm}$ ) and S. aureus (2PKB: $10 \mathrm{~mm}$ ) (2PKT: $12 \mathrm{~mm})$. Amoxicillin antibiotic inhibition zones against $E$. coli $(40 \mathrm{~mm})$ and $S$. aureus $(20 \mathrm{~mm}$ ) (Table 3 ). The antimicrobial activity of LAB competes favorably with standard antibiotics used as control. Isolate LAB Sui Wu'u showed the highest zone of inhibition for E. coli while the antimicrobial activity decreased with time.

\section{Molecular identify}

LAB isolates were selected to identify $16 \mathrm{~S}$ rRNA gene sequences and be analyzed phylogenetically (Fig. 3). The 16S rRNA encoding gene can be

Table 1: Colony morphology and cell morphology lactic acid bacteria

\begin{tabular}{lll}
\hline Isolate & Colony morphology & Cell morphology \\
\hline 2KH & Punctiform creamy white convex & Coccus \\
2ST & Punctiform creamy white flat & Coccus \\
2PKB & Circular creamy white flat & Bacilli \\
2PKT & Circular creamy white convex & Bacilli \\
3SP & Circular creamy white convex & Bacilli \\
\hline
\end{tabular}

Table 2: Characteristic of Isolate LAB Sui Wu'u

\begin{tabular}{|c|c|c|c|c|c|}
\hline \multirow[t]{2}{*}{ Variables } & \multicolumn{5}{|c|}{ Isolate code } \\
\hline & $2 \mathrm{KH}$ & $2 S T$ & 2PKB & 2PKT & 3SP \\
\hline \multicolumn{6}{|l|}{ Cell morphology } \\
\hline Motility & - & - & - & - & - \\
\hline \multicolumn{6}{|l|}{ Biochemical } \\
\hline Catalase & - & - & - & - & - \\
\hline Endospore & - & - & - & - & - \\
\hline Fermentation type & Ho & Ho & Ho & Ho & Ho \\
\hline \multicolumn{6}{|l|}{ Physiological } \\
\hline $\mathrm{NaCl} 4 \%$ & + & + & + & + & + \\
\hline $\mathrm{NaCl} 6.5 \%$ & + & + & + & + & + \\
\hline Temp. $10^{\circ} \mathrm{C}$ & - & - & - & - & - \\
\hline Temp. $45^{\circ} \mathrm{C}$ & + & + & + & + & + \\
\hline Temp. $50^{\circ} \mathrm{C}$ & + & + & + & + & + \\
\hline $\mathrm{pH} 4.4$ & + & + & + & + & + \\
\hline pH 9.6 & - & - & - & - & - \\
\hline
\end{tabular}

(+): Positive/tolerance, (-): Negative/intolerance/nonmotile,

Ho: Homofermentatif 


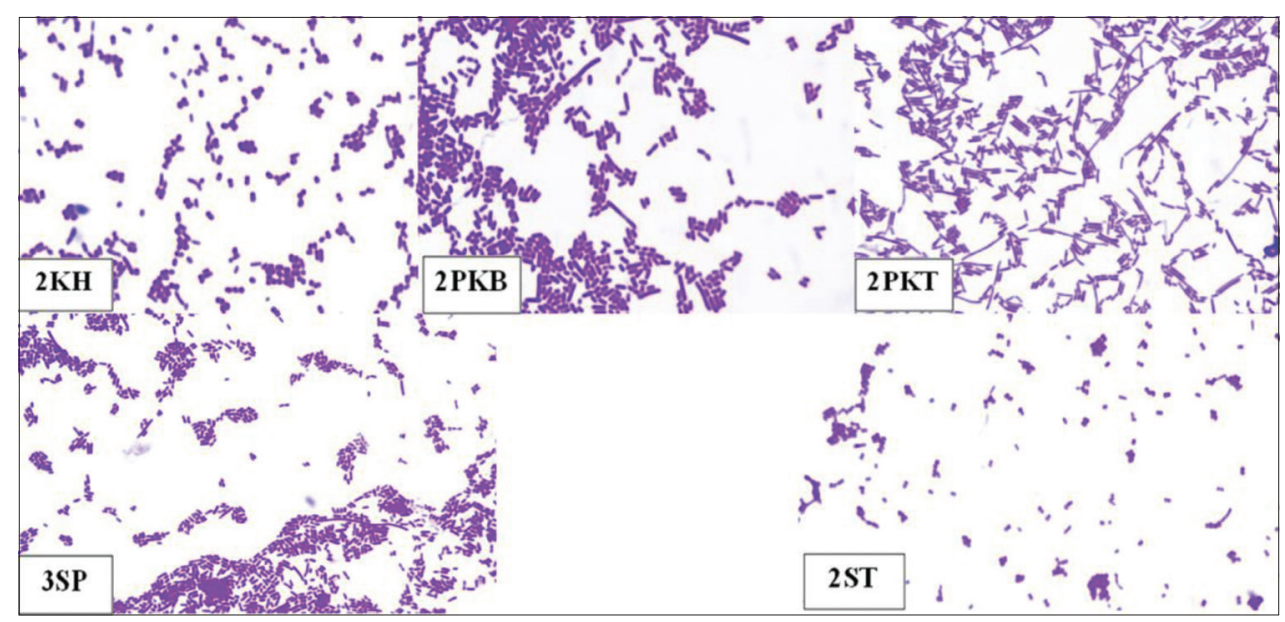

Fig. 1: Gram staining lactic acid bacteria isolated of Sui Wu'u
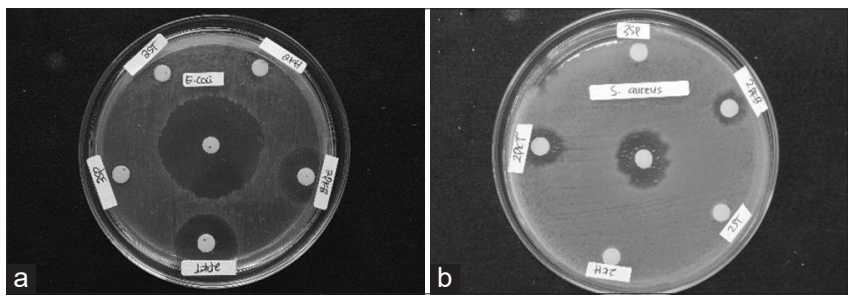

Fig. 2: Zones of inhibition lactic acid bacteria against Escherichia coli and Staphylococcus aureus. *(a) E. coli, (b) S. aureus

Table 3: Clear zone diameter indicating antimicrobial activity

\begin{tabular}{lll}
\hline Lactic acid bacteria & \multicolumn{2}{l}{ Inhibition zone $(\mathrm{mm})$} \\
\cline { 2 - 3 } & Staphylococcus aureus & Escherichia coli \\
\hline 2KH & - & - \\
2ST & - & - \\
2PKB & 10 & 17 \\
2PKT & 12 & 20 \\
3SP & - & - \\
Antibiotics & 20 & 40 \\
\hline
\end{tabular}

used to determine taxonomies, phylogeny (evolutionary relationships), and estimate bacterial rates of species divergence [29]. The results of the electrophoresis of pure Polymerase Chain Reaction CR products (Fig. 4).

\section{DISCUSSION}

\section{Isolation and characterization of LAB}

Based on research conducted, obtained five isolates from the results of the isolation of LAB from the source of Sui Wu'u. Differences of isolates were seen based on morphology of isolate colonies consisting of shape, edges, elevation, color, and diameter of the isolates. Colonies obtained from isolation in the form of circular and punctiform. The edge of the colony is entire or slippery. Convex colony elevation, flat colony elevation is only owned by 2PKB and 2ST. The color of the colony is milky white and the diameter of the colony is in the range of $0.2-0.5 \mathrm{~cm}$. Differences in each colony isolate based on morphological characters can be seen in Table 1 .

LAB have the characteristics of Gram positive, non-spore, negative catalase, and nonmotile. The results of the identification test of LAB can be seen in Table 2. All isolates obtained were Gram positive, rod shaped, and non-spore-forming, gave a negative reaction in the catalase test, and non-motile. Based on the results of Gram staining, the results obtained are that all isolates have a positive gram character. According to Hardy [30], LAB are Gram-positive bacteria because they do not undergo decolorization and still bind to the violet crystal violet color at the final stage of staining. Based on the results of Gram staining can be observed also the form of the bacterial cell. The shape of the bacterial cell is based on observations of stem and round.

Catalase test results, all isolates have non-catalase characteristics or give negative results on catalase testing. According to Alfonzo [31], LAB are negative catalase bacteria because they do not produce catalase enzymes that can break down hydrogen peroxide. Siti [32] added that LAB are generally microaerophilic to obligate anaerobic, which means that if there is $\mathrm{O}_{2}$ during growth, it will be toxic and can inhibit the growth of LAB.

The endospora staining results, in all the isolates observed, were nonspore characteristics or did not produce spores. According to Axelsson [33], LAB are bacteria that do not form spores, so when an endospora is stained, vegetative cells appear to produce a pink color at the end of the staining stage. Fardiaz [34] added, in staining endospores, endospores will be seen on a microscope in the form of green dots.

Based on the results of the motility test, all isolates were nonmotile or immobile. Cell movement is observed visually by inoculating on semi-solid upright media. According to Fardiaz [34], LAB have immovable properties. Characterization based on the phenotypic characteristics included isolate growth test at different $\mathrm{pH}$, temperature, and salinity, as well as observations on isolate type fermentation. Phenotype characteristics can also be performed to determine the genera of the isolates observed.

The observation of the characterization of selected isolates is shown in Table 2. The selected isolates were observed growth in the different salt concentrations, conducted by growing isolates in the variation of the $\mathrm{NaCl}$ concentration of $4 \%$ and $6.5 \%$. Based on the results of testing, the growth of isolates at different salt concentrations, isolates can grow salinitas concentrations of $4 \%$ and $6.5 \%$. According to Axelsson [33], LAB were able to grow at salinitas concentration of 3-7\% if they are rod shaped; they belong to the Lactobacillus genera. Selected bacteria growth observed at different $\mathrm{pH}$ conditions have variations in $\mathrm{pH} 4.4$ and 9.6, respectively, represented for acid and alkaline $\mathrm{pH}$ based on test results isolates growth at different $\mathrm{pH}$ showed that isolates were able to grow at $\mathrm{pH} 4.4$ and unable to grow at $\mathrm{pH}$ 9.6.

According to Axelsson [33], LAB were able to grow at pH 4.4 and cannot to grow at $\mathrm{pH} 9.6$ if it is in the form of a stem, then it belongs to the Lactobacillus genera. Selected isolates were observed to grow at different temperatures, conducted by growing isolates at $10^{\circ} \mathrm{C}$ and $45^{\circ} \mathrm{C}$. Based on the results of testing, the growth of isolates at different temperatures, it was found that the isolates were able to grow at temperatures of $10^{\circ} \mathrm{C}$ and $45^{\circ} \mathrm{C}$. According to Axelsson [33], LAB were able to grow at temperatures of $10^{\circ} \mathrm{C}$ and $45^{\circ} \mathrm{C}$ when they are rod shaped, are included in the Lactobacillus genera. 


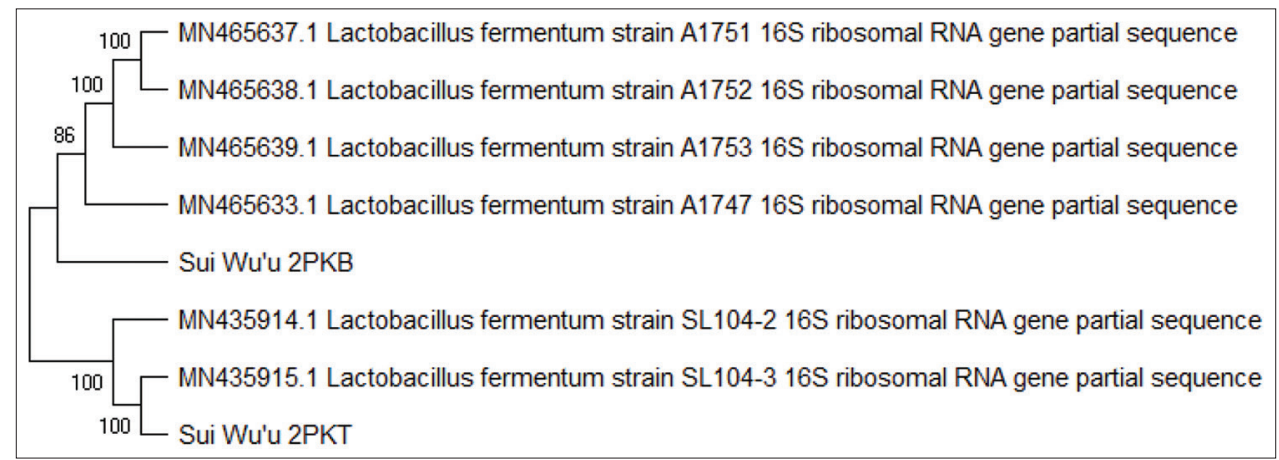

Fig. 3: Neighbor-joining tree of LAB Sui Wu'u showing phylogenetic relationship by MEGA 10

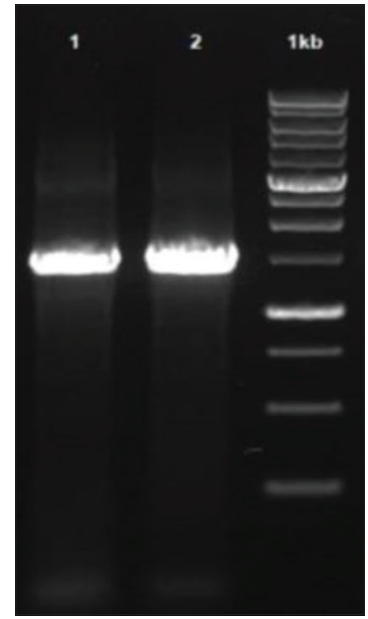

Fig. 4: Polymerase chain reactions product lactic acid bacteria isolates in $1 \%$ agarose gel. ${ }^{*} 1=2 \mathrm{PKB}, 2=2 \mathrm{PKT}, 1 \mathrm{~kb}=\mathrm{DNA}$ marker

\section{Antimicrobial assay}

To select and obtain the most potent LAB isolates of to suppress the growth of pathogenic bacteria such as $S$. aureus and E. coli, the isolates were screened by using the disk diffusion well method. This study uses positive controls, such as antibiotics, because the tests were performed to determine the ability of the isolates to inhibit the growth of pathogenic bacteria.

The test results showed a zone of inhibition marked by the emergence of a clear zone around the selected LAB isolate colonies after being incubated for 24-48 h, both in S. aureus and E. coli cultures (Fig. 2). Inhibition zone diameters formed by selected LAB isolates against $S$. aureus and E. coli vary the results of the measurement of clear zone diameters can be seen in Table 3. The highest inhibition of $S$. aureus was shown by $2 \mathrm{PKT}$ isolates which were $12 \mathrm{~mm}$, while the lowest measured inhibition shown by $2 \mathrm{PKB}$ isolates which is $10 \mathrm{~mm}$. The highest inhibition of E. coli was shown by $2 \mathrm{PKT}$ isolate that was equal to $20 \mathrm{~mm}$, while the lowest inhibition was shown by $2 \mathrm{PKB}$ isolate which was $17 \mathrm{~mm}$.

Clear zone of inhibition was thought to be caused by antimicrobial activity produced by the LAB isolates. The inhibition shown by the $\mathrm{LAB}$ isolates was thought to be caused by changes in $\mathrm{pH}$ due to the production of organic acids during fermentation. As reported by Lee et al. [35], the ability of LAB to inhibit the growth of pathogenic bacteria is shown by the wide clear zone produced during antimicrobial testing and is related to the ability of LAB to produce secondary metabolites such as lactic acid, acetic acid, and bacteriocin. The main inhibitory effect is speculated on the main metabolic pathway of LAB, which means the fermentation pathway. LAB use fermentation pathways to produce cellular energy and produce organic acids such as lactic acid as they grow [19].
Lactic acid produced by LAB isolates diffuses into the growing media of test bacteria so that it can interfere with the integrity of the pathogenic bacterial cell membranes. Damage to the cell membrane causes the nutrients needed by the test bacteria to grow cannot be absorbed so that the metabolic process does not work as it should and causes its growth to be inhibited. Lactic acid is one of the inhibitor compounds produced by LAB and is the main end product of carbohydrate catabolism because from the process of converting this carbon source produced at least $50 \%$ lactic acid, so this group of bacteria is called LAB [36].

Acid produced during the metabolic process by LAB will cause a decrease in $\mathrm{pH}$ and cause pathogenic microbes and food destroyers that generally cannot stand the acidic atmosphere will be inhibited [37]. Accumulation of acidic end products results in a decrease in $\mathrm{pH}$ and will inhibit the growth of Gram-positive and Gram-negative bacteria. The activity of lipophilic acids such as lactic acid in an undissociated form can penetrate microbial cells, and at higher intracellular $\mathrm{pH}$, dissociates to produce hydrogen ions, and interferes with the function of essential metabolites, translocation of substrate, and oxidative phosphorylation, thereby reducing intracellular $\mathrm{pH}$. The difference in LAB antimicrobial activity against several test microbes is based on differences in the structure of the test microbial cell walls, different concentrations of antimicrobial compounds can also produce different inhibitory zones [28].

\section{Molecular identify}

Genomic isolation and 16S rRNA reaction of LAB: The electrophoresis results in Fig. 4 indicate that the 16S rRNA gene region of the fermented pork (Sui Wu'u) of Bajawa was successfully amplified. Successful amplification of the 16S rRNA gene was indicated by the appearance of a $1.5 \mathrm{~kb}$ PCR product, which was the expected fragment size when using the 27F forward primer AGAGTTTGATCCTGGCTGAG with the reverse primer $1492 \mathrm{R}$ GTTTACCTTACGACTT. A phylogenetic tree based on 16S rRNA gene sequence analysis is shown in Fig. 4.

Based on the BLAST search result, the bacterial isolate 2PKB and 2PKT have confirmed L. fermentum strain HB bacteria with $100 \%$ identification value and $98.93 \%$ query cover and $L$. fermentum strain HT with $100 \%$ identification value and $99.23 \%$ query cover. The phylogenetic tree shows that the nearest distant neighbor is the $L$. fermentum strain HB and HT. This indicates that the LAB isolated from Sui Wu'u were L. fermentum strain HB and HT. Hagstrom et al. [38] suggested that isolates with a $16 \mathrm{~S}$ rRNA sequence similarity over $97 \%$ may represent the same species, while sequence similarity between 93 and $97 \%$ indicates the same genus but different species.

Based on previous research Bao et al. [39] suggested that cell-free supernatant from L. fermentum can significantly inhibit the growth of Gram-positive bacteria (Listeria monocytogenes C53-3, S. aureus AC1.2456) and Gram-negative bacteria (E. coli 0157 882365, Shigella flexneri CMCC (B) 51592, Salmonella typhimurium S50333). In pozol (corn) fermentation, $40 \%$ of LAB are found that have amylolytic ability. L. fermentum UN01 is able to produce bacteriocin with the highest activity 
at $37^{\circ} \mathrm{C}$ and $\mathrm{pH} 2.0$ [17]. L. fermentum SBS001 isolated from seawater showed inhibitory activity against ten pathogenic bacteria, namely, S. aureus (12 mm), Pseudomonas aeruginosa (12 mm), Salmonella Typhi $(10 \mathrm{~mm})$, Salmonella paratyphi $(8 \mathrm{~mm})$, Klebsiella oxytoca, $(8 \mathrm{~mm})$ E. coli $(8 \mathrm{~mm})$, Lactobacillus bulgaricus $(8 \mathrm{~mm})$, Vibrio cholerae $(8 \mathrm{~mm})$, Proteus mirabilis (7 mm), and Klebsiella pneumoniae (7 mm) [40]. L. fermentum and L. plantarum isolates in Dangke [21], L. fermentum B111K from cow's milk can produce bacteriocin and are antagonistic [41]

\section{CONCLUSION}

Based on the results of the study, five LAB were successfully isolated, have tolerance of viability at temperatures, $\mathrm{NaCl}$ concentration, and homofermentative. Categorized as Gram-positive bacteria and in the form of coccus, rod. Are antagonistic because they can inhibit the growth of Gram negative and positive pathogenic bacteria. Identified based on the 16S rRNA gene is L. fermentum. Therefore, LAB from Sui Wu'u have the potential as a bio preservative is recommended to food processing industries to enhance the extension of shelf life of food products and reduction in food contamination which causes illness to human beings.

\section{ACKNOWLEDGMENTS}

The authors are grateful to the UPT Laboratorium Terpadu Universitas Diponegoro, PT. Genetika Science Indonesia, supervisor of the research, my parents, and friends of Magister Biology Faculty Science and Mathematics. The authors did not receive any funding for this study.

\section{AUTHORS' CONTRIBUTIONS}

Rosalina Yuliana Ayen designed, conducted, and wrote up the search and Endang Kusdiyantini and Sri Pujiyanto provided guidance and helped with manuscript revision.

\section{CONFLICTS OF INTEREST}

The authors declare that there are no conflicts of interest.

\section{REFERENCES}

1. Heny K, Satrio BH, Robertus TM. Functional food from Indonesian local plants. Methane 2016;12:26-30.

2. Wirawati CU, Sudarwanto MB, Lukman DW, Wientarsih I, Srihanto EA. Diversity of lactic acid bacteria in dadih produced by either back-slopping or spontaneous fermentation from two different regions of West Sumatra, Indonesia. Vet World 2019;12:823-9.

3. Melia S, Yuherman Y, Jaswandi J, Purwati E. Selection of buffalo milk lactic acid bacteria with probiotic potential. Asia J Pharm Clin Res 2018;11:186-9.

4. Sanchart C, Rattanaporn O, Haltrich D, Phukpattaranont P, Maneerat S. Enhancement of gamma-aminobutyric acid (GABA) levels using an autochthonous Lactobacillus futsaii CS3 as starter culture in Thai fermented shrimp (Kung-Som). World J Microbiol Biotechnol 2017:33:152.

5. Nuraida L. A review: Health promoting lactic acid bacteria in traditional Indonesian fermented foods. Food Sci Hum Wellness 2015:4:47-55.

6. Sieladie DV, Francois Z, Marie KP, Cresci A, Florence FA. Probiotic properties of lactobacilli strains isolated from raw cow milk in the Western Highlands of Cameroon. Innov Rom Food Biotech $2011 ; 9: 12-28$

7. Coeuret V, Dubernet S, Bernardeau M, Gueguen M, Vernoux JP. Isolation, characterisation and identification of lactobacilli focusing mainly on cheeses and other dairy products. Le Lait 2003;83:269-306.

8. Oyetayo VO, Adetuyi FC, Akinyosoye FA. Safety and protective effect of Lactobacillus acidophilus and Lactobacillus casei used as probiotic agent in vivo. Afr J Biotech 2003;2:448-52.

9. Abdelbasset M, Kirane D. Antimicrobial activity of autochthonous lactic acid bacteria isolated from Algerian traditional fermented milk "Raïb". Afr J Biotech 2008;7:2908-14.

10. Biller JA, Korkina L, Orhan IE, Georgiev MI. Treatment of recurrent clostridium difficile colitis with Lactobacillus Gg. J Pediatr Gastroenterol Nutr 1995;21:224-6.

11. Maragkoudakis PA, Zoumpopoulou G, Miaris C, Kalantzopoulos G, Pot B, Tsakalidou E. Probiotic potential of Lactobacillus strains isolated from dairy products. Int Dairy J2006;16:189-99.
12. Temmerman R, Pot B, Huys G, Swings J. Identification and antibiotic susceptibility of bacterial isolates from probiotic products. Int J Food Microbiol 2003;81:1-10.

13. Reis JA, Paula AT, Casarotti SN, Penna AL. Lactic acid bacteria antimicrobial compounds: Characteristics and applications. Food Eng Rev 2012;4:124-40.

14. de LeBlanc AD, Perdigon G. The application of probiotic fermented milks in cancer and intestinal inflammation. Proc Nutr Soc 2010;69:421-8

15. Bharti V, Mehta A, Jain N, Singh S, Ahirwal L. In vivo acute toxicity, antibacterial, antiaquatic fungal, anthelminthic activity of Lactobacillus plantarum KP894100 and Lactobacillus acidophilus KP942831. Asian J Pharm Clin Res 2016;9:79-83.

16. Thirabunyanon M, Hongwittayakorn P. Potential probiotic lactic acid bacteria of human origin induce antiproliferation of colon cancer cells via synergic actions in adhesion to cancer cells and short-chain fatty acid bioproduction. Appl Biochem Biotechnol 2013;169:511-25.

17. Udhayashree N, Senbagam D, Senthilkumar B, Nithya K, Gurusamy R. Production of bacteriocin and their application in food products. Asia Pac J Trop Biomed 2012;2:406-10.

18. Rhee SJ, Lee, JE, Lee, CH. Importance of lactic acid bacteria in Asian fermented foods. Microb Cell Fact 2011;10:5-10.

19. Fenta L, Assefa A. In vitro evaluation of antibacterial activity of lactic acid bacteria isolated from-ergo and Qotchqotcha, Ethiopian traditional fermented foods, against some selected food borne pathogens. Int J Sci Techno Res 2017;6:230-8.

20. Adeyemo SM, Agun TF, Ogunlusi ED. Antimicrobial activity of lactic acid bacteria isolated from 'Pupuru': An African fermented staple against food borne-pathogens. J Mol Bio Biotech 2018;3:1-5.

21. Holt JG, Krieg NR, Peter HA, Staley JT, Williams ST. Bergey's Manual of Determinative Bacteriology. $9^{\text {th }}$ ed. Baltimore, Maryland, USA: Williams and Wilkins; 1994

22. Syah SP, Sumantri C, Arief II, Taufik E. Isolation and identification of indigenous lactic acid bacteria by sequencing the 16S rRNA from Dangke, a traditional cheese from Enrekang, South Sulawesi. Pak J Nutri 2017;16:384-92

23. Arief II, Astawan M, Jenie BS, Fujiyama K, Witar AB. Identification and probiotic characteristics of lactic acid bacteria isolated from Indonesian local beef. Asian J Anim Sci 2015:9:25-36.

24. Kumar PR, Amandeep K, Neha K, Pranay J. Fermented sauerkraut juice as antimicrobial agent: In vitro study. Int Res J Pharm 2013;4:46-9.

25. Rinto R. Lactic acid bacteria from peda, bekasam, terasi and rusip inhibitors Morganella morganii (forming histamine). J Appl Agric Res 2017; 11:99-103.

26. Prescott LM, Harley JP, Klein DA. Clinical microbiology. In: Microbiology. New York: McGraw-Hill; 2005. p. 725.

27. Hudzicki J. Kirby-Bauer Disk Diffusion Susceptibility Test Protocol. Washington, DC: American Society for Microbiology; 2016.

28. Kasi PD, Ariandi A, Mutmainnah H. Antibacterial test of lactic acid bacterial isolates isolated from sago liquid waste against pathogenic bacteria. J Trop Biol 2017;5:97-101.

29. Imelda KS, Ira A, Agung S. Identification of bite marks with Chelite method DNA extraction (bite marks identification with Chelex methods in DNA extraction). Dent J 2013;46:107-12.

30. Hardy J. Gram's Serendipitous Stain. Santa Maria, CA: CLS, SM (ASCP); 2016

31. Alfonzo AG, Ventimiglia O, Corona R, Di Gerlando R, Gaglio N, Francesca G, et al. Diversity and technological potential of lactic acid bacteria of wheat flours. Food Microbiol 2013;36:343-54

32. Siti Z. Isolation, Characterization and Test of Antioxidant Activity of Lactic Acid Bacteria Producing Gamma Aminobutyric Acid from Several Commercial Virgin Coconut Oil Products Circulating in Padang City Doctoral Dissertation. Padang, Indonesia: Andalas University; 2017.

33. Axelsson L. Lactic acid Bacteria: Classification and physiology. In: Salminen S, Wright, AV, Ouwehand A, editors. Lactic Acid Bacteria. New York: Marcel Dekker, Inc.; 2004.

34. Fardiaz S. Mikrobiologi Pangan. Bogor: Pusat Antar Universitas Institut Pertanian; 1992.

35. Lee, JS, Lee KC, Ahn JS, Mheen TI, Pyun YR, Park YH. Weissella koreensis sp. nov, isolated from Kimchi. Int J Syst Evol Microbiol 2002:52:1257-61.

36. Bartkiene E, Krungleviciute V, Antanaitis R, Kantautaite J, Kucinskas A, Ruzauskas M, et al. Antimicrobial activity of lactic acid bacteria multiplied in an alternative substrate and their influence on physiological parameters of new-born calves. Vet Med 2016;61:653-62.

37. Zahari WI. Antimicrobial Activities and Antibiotic Sensitivity of Lactic 
Acid Bacteria (LAB) from Fermented Durian Fresh. Vol. 6. In: 2015 Innovation and Commercialization of Medical Electronic Technology Conference; 2015. p. 105-10.

38. Hagstrom A, Pinhassi J, Zweifel, Ulla L. Biogeographical diversity among marine bacterioplankton. Aquat Microb Ecol 2000;21:231-44.

39. Bao Y, Zhang Y, Liu Y, Wang S, Dong X, Zhang H. Screening of potential probiotic properties of Lactobacillus fermentum isolated from traditional dairy products. Food Control 2010;21:695-701.

40. Singh R, Sivasubramani K, Jayalakshmi S, Kumar SS, Selvi C. Isolation and production of bacteriocin by marine Lactobacillus fermentum SBS001. Int J Curr Microbiol Appl Sci 2013;2:67-73.

41. Burhan H, Priyambada S, Taufik E, Arief I. Potential of lactic acid bacteria isolated from Dangke and Indonesian beef as hypocholesterolaemic agent. Media Petern 2017;40:136-42. 